\title{
Dampak Luka Batin Terhadap Pelayanan Mahasiswi Sekolah Tinggi Theologia Jaffray Makassar
}

\author{
Dewiyana
}

\begin{abstract}
Abstrak
Fokus penulis dalam skripsi ini adalah melihat dampak dari luka batin terhadap pelayanan yang dilakukan oleh Mahasiswi STT Jaffray Makassar. Berdasarkan hasil penelitian yang dilakukan maka penulis memberikan kesimpulan yaitu sebagai berikut: Pertama, ada beberapa faktor penyebab luka batin dalam kehidupan mahasiswi yaitu penolakan, lahir dari keluarga broken home, kekerasan fisik, pelecehan. Faktor-faktor tersebut sangat memengaruhi pertumbuhan rohani dan terkhusus pelayanan bahkan bisa merusak hubungan dengan sesama. Kedua, luka batin yang disimpan dan tidak dibereskan akan menimbulkan dampak yang negatif dan memengaruhi seluruh aspek kehidupan. Memengaruhi secara psikologis, fisik, emosi, spiritual, dan intelektual. Ketiga, salah satu jalan untuk pemulihan adalah dengan mengetahui apa pokok permasalahnya, serta adanya keterbukaan, dan melibatkan Allah dalam proses tersebut. Keempat, pemulihan adalah suatu proses dalam ketetapan hati untuk terus berjuangan dan melangkah memperbaiki keadaan yang terluka itu bisa disembuhkan atau dipulihkan secara total. Kelima, dalam proses pemulihan, maka harus dilakukan dengan pelayanan konseling atau bimbingan rohani.
\end{abstract}

Kata-kata Kunci: Luka batin, Pelayanan, Mahasiswi, Sekolah Tinggi Theologia Jaffray Makassar.

\section{Pendahuluan}

\section{Latar Belakang Masalah}

Hidup manusia tidak lepas dari konflik dan penderitaan, bahkan sering kali manusia berhadapan dengan konflik atau penderitaan ringan, tetapi kadangkala 
konflik yang terjadi begitu berat sehingga menimbulkan luka batin atau truma. ${ }^{1}$ Dan luka itu sangat mengganggu kehidupan seseorang yang mengalami luka batin akibat perlakuan orang yang tidak menyenangkan, maka beberapa dari mereka sulit untuk membangun hubungan yang baik dengan sesamanya. Bahkan mereka cenderung memilih menjauh dari kumpulan banyak orang, mereka merasa tenang dengan keadaan atau situasi yang tidak ada orang lain disekitar mereka. ${ }^{2}$ Margaret Hill et al. mengatakan dalam bukunya, Menyembuhkan Luka Batin Akibat Trauma:

Beberapa orang dengan luka batin selalu tegang. Setiap suara keras membuat mereka kaget. Mereka ketakutan terus- menerus, dan seolah mengira akan terjadi sesuatu yang buruk atas mereka setiap saat. Sebagian mereka begitu tegang sehingga tidak dapat tidur, atau mereka gemetaran atau berdebar jantungnya. Atau mungkin mereka kesulitan bernafas, pusing, seperti mau pingsan. Sebagian orang dengan hati yang terluka kelihatan sangat marah, benci kepada orang lain dan bisa bersikap keras. Beberapa orang dengan luka batin merasa sangat sedih, mengalami depresi dan mungkin juga banyak menangis dan beberapa orang dengan luka batin cenderung menjauhi segala sesuatu yang mengingatkan mereka kepada pengalaman trauma yang pernah mereka alami. ${ }^{3}$

Pengalaman pahit itu tidak bisa disimpan sendiri karena luka itu akan semakin parah jika tidak dibersihkan dan diobati. Julianto Simanjuntak mengatakan dalam bukunya Seni Merayakan Hidup yang Sulit,

Menceritakan masalah memang kadang menambah luka dan rasa malu. Hal itu menggoda kita tetap menyimpan luka. Namun, Rick Warren pernah menulis, bahwa Allah itu tidak pernah menyia-nyiakan luka kita. Allah mau dan siap menggunakan luka hidup kita berdaya guna bagi sesama kita. Karya dan pelayanan kita yang besar selalu datang dari pengalaman luka yang besar. ${ }^{4}$

Dari kutipan di atas dapat disampaikan bahwa orang yang mengalami luka batin cenderung tergoda untuk menutupi masalahnya dan enggan untuk

\footnotetext{
${ }^{1}$ Harriet Hill, Richard Bagge, dan Pat Miersma, Menyembuhkan Luka Batin Akibat Trauma (Jakarta: Gloria Graffa, 2006), 6.

2"Mengobati Luka Batin,"diakses 31 Maret 2016, http://www.lukabatin.com.

${ }^{3}$ Harriet Hill, Richard Bagge, dan Pat Miersma, Menyembuhkan Luka Batin Akibat Trauma(Jakarta: Gloria Graffa, 2006), 35.

${ }^{4}$ Julianto Simanjuntak, Seni Merayakan Hidup Yang Sulit (Jakarta: Gramedia Pustaka Utama, 2008), 21.
} 
menceritakan kepada orang lain sehingga luka itu semakin parah dan sulit disembuhkan. Mereka berpikir menceritakan masalah sama saja mempermalukan diri sendiri dan mereka sangat takut dianggap orang yang paling rendah dan meresa orang yang tidak layak dari manusia lainnya. ${ }^{5}$ Dan mereka yang mengalami luka batin cenderung meresa rendah diri dan mudah tersinggung dengan hal-hal yang membuat mereka kecewa. Pengalaman di masa lalu yang mereka alami seperti putus cinta, penolakan, pelecehan seksual, kekerasan fisik dan penghianatan teman yang sangat menyakitkan bagi mereka di masa lalu atau di masa yang sekarang sehingga sangat mempengaruhi emosional mereka bahkan kegiatan yang mereka lakukan. ${ }^{6}$

Luka batin atau kepahitan hingga saat ini masih banyak anak-anak di kampus yang belum pulih terkhusus yang wanita. Beberapa yang pernah menceritakan masalahnya kepada penulis dan ada juga yang penulis ketahui sendiri masalah yang di alami oleh teman- teman di kampus ini. Dampak emosional ini sempat dilihat oleh penulis di kampus STT Jaffray Makassar.

Fokus penulis dalam skripsi ini adalah melihat dampak dari luka batin terhadap pelayanan yang dilakukan oleh Mahasiswi STT Jaffray Makassar. Seperti yang dikatakan oleh Rick Warren dari kutipan diatas bahwa pengalaman luka yang besar itu bisa dijadikan kekuatan untuk memulai pelayanan yang besar. Namun yang terjadi kepada sebagian orang malah sebaliknya, justru kebanyakan orang meratapi masalahnya dan mengganggap Allah tidak memperdulikan masalahnya akhirnya menjauhkan diri dari persekutuan dan merasa dihantui oleh rasa bersalah merasa tidak layak terlibat dalam pelayanan di gereja atau diberbagai persekutuan lainnya. ${ }^{7}$ Dan ada juga yang justru menyibukan diri dengan berbagai macam kegiatan dan pelayanan untuk menutupi masalah atau luka yang mereka alami karena mereka berpikir luka batin itu bisa sembuh dengan sendirinya dan dengan berjalannya waktu. Inilah yang menggoda sehingga kebanyakan dari mereka yang terluka menyembunyikan masalah mereka dari orang lain karena takut malu dan takut dianggap rendah oleh orang lain padahal menyembunyikan masalah atau luka batin justru menambah masalah dan luka itu semakin parah. "Masalah itu akan berkembang jika didiamkan, sebab masalah selalu tumbuh dalam kegelapan. Menyimpan masalah atau dosa, sering kali menyuburkan kesombongan. Karena mereka tidak ingin orang lain tahu keadaan mereka yang sesungguhnya." 8

${ }^{5}$ Dan B. Allender, Hati Yang Luka (Jakarta: BPK Gunung Mulia, 2001), 47-48.

${ }^{6}$ Dan B. Allender, Hati Yang Luka, 66-77.

${ }^{7}$ Irene Hoft, Anda Merasa Ditolak (Jakarta: BPK Gunung Mulia, 2011), 22.

8 Julianto Simanjuntak,Seni Merayakan Hidup Yang Sulit (Jakarta: Gramedia Pustaka Utama, 2008), 11-12. 
Kata pelayanan tidak dapat dipisahkan dari seseorang yang menuntut ilmu di Sekolah Tinggi Teologi. Demikian juga dengan para Mahasiswi yang ada di Sekolah Tinggi Teologi Jaffray Makassar setiap Mahasiswi diwajibkan untuk melayani di gereja lokal tidak hanya di gereja Kemah Injil saja, namun di berbagai dominasi. Pelayanan di gereja lokal adalah salah satu syarat bagi Mahasiswi untuk bisa praktek di lapangan dan untuk melatih Mahasiswi melayani dengan baik agar mereka juga mengerti pentingnya pelayanan yang baik dan dilakukan dengan ketekunan serta tanggung jawab agar kedepan para mahasiswi tidak merasa bahwa palayanan itu sesuatu hal yang baru dan sulit. Peraturan yang dibuat oleh pihak sekolah sangat membantu para mahasiswi untuk menggali kemampuan atau talenta meraka di bidang apa saja sehingga mereka bisa mengembangkan kemampuan itu melalui pelayanan di gereja lokal tersebut.

Dalam gereja lokal biasanya mahasiswi dilibatkan dalam berbagai macam kegiatan atau pelayanan dalam gereja tersebut, seperti menjadi guru sekolah minggu, singer, pemimpin pujian, pemain musik, berkhotbah, dan melatih paduan suara. Dalam pelayanan tersebut tidak hanya dituntut memiliki talenta atau skill saja, namun sangat dibutuhkan karakter yang baik mahasiswi juga harus bisa memberi dampak bagi semua anggota jemaat digereja tersebut agar anggota jemaat melihat karakter Kristus didalam diri seorang pelayan Tuhan.

Penting dari sebuah pelayanan bahwa orang yang dilayani mampu melihat karakter Kristus itu nyata didalam para pelayan-Nya. Ketika seorang pelayan atau hamba Tuhan tidak memiliki karakter Kristus didalam dirinya biasanya tidak bisa menjadi berkat bagi orang lain, justru sebaliknya malah menjadi batu sandungan bagi orang lain. Demikian juga dengan seorang mahasiswi jika dia memiliki luka batin pada masa lalunya yang belum disembuhkan akan sangat berpengaruh bagi pelayanannya karena luka batin itu kadang kala tidak disadari. Bahkan beberapa orang yang mengalami luka batin mengelak bahwa ia sedang menyimpan luka. ${ }^{9}$ Dan luka itu biasanya akan terbongkar atau terlihat ketika seseorang yang mengalami luka batin itu dalam kondisi terhimpit dan dalam tekanan berat. Orang yang sedang menyimpan luka batin biasanya mudah tersinggung ketika ditegur atau dinesehati ia cenderung meledak-ledak ketika sedang marah terhadap orang lain. ${ }^{10}$ Hal seperti itu yang diamati penulis dan ada beberapa yang pernah penulis temui dalam kampus ini mengalami hal demikian, ketika penulis mengamati dan mendekati orang tersebut ternyata ada banyak kemarahan dan kekecewaan yang belum dibereskan sehingga kemarahan itu setika-tika bisa meluap tidak perduli

\footnotetext{
${ }^{9}$ Julianto Simanjuntak, Mengenali Monster Pribadi (Tangerang: PELIKAN Indonesia, 2013), 3.

${ }^{10}$ R.M. Drie S. Brotosudarmo, Etika Kristen Untuk Perguruan Tinggi (Yogyakarta: ANDI 2007), 37.
} 
siapa yang akan menjadi sasaran kemarahannya. ${ }^{11}$ Dan penulis berpikir bahwa ini sangat berpengaruh dan berdampak terhadap pelayanan mereka karena luka batin atau kepahitan, dan sebagainya itu adalah sesuatu hal yang tidak berkenan dihadapan Allah ketika apa yang kita lakukan tidak berkenan dihadapan Allah maka itu juga tidak mungkin bisa menjadi berkat bagi orang lain. Karena Allah menginginkan anak-anak-Nya untuk saling mengampuni karena itu adalah salah satu karakter Allah yang harus ada didalam diri pelayan-Nya. ${ }^{12}$

\section{Pokok Masalah}

Dari pembahasan yang dipaparkan pada latar belakang di atas, penulis melihat bahwa yang menjadi pokok masalah dalam penulisan skripsi ini adalah: Sejauh mana dampak luka batin terhadap pelayanan mahasiswi STT Jaffay Makassar.

\section{Tujuan Penelitian}

Berdasarkan pembahasan di atas, maka penulis menguraikan tujuan penulisan sebagai berikut: Menjelaskan dampak luka batin terhadap pelayanan mahasisiwi STT Jaffray.

\section{Manfaat Penelitian}

Pertama, agar karya tulis ini dapat dijadikan pedoman bagi penulis dalam persiapan pelayanan sehingga dapat menolong dan membimbing orang yang pernah mengalami luka batin dalam hidupnya.

Kedua, menolong mahasiswi supaya bisa terbuka terhadap orang lain atau konselor atas luka batin yang mereka alami.

Ketiga, untuk memenuhi salah satu persyaratan akademis dalam penyelesaikan program Serjana Teologi di STT Jaffray Makassar.

\section{Metode Penelitian}

Dalam penulisan skripsi ini, penulis menggunakan metode kuantitatif dengan teknik pengumpulan data sebagai berikut:

Pertama, penulis menggunakan kajian kepustakaan yaitu penelitian terhadap buku-buku yang ada kaitanya dengan pembahasan skripsi.

\footnotetext{
2013), 41.

${ }^{11}$ Julianto Simanjuntak, Mengenali Monster Pribadi (Tangerang: PELIKAN Indonesia,

${ }^{12}$ William Hines, Meninggalkan Masa Lalu (Jakarta: IMMANUEL 2009),113.
} 
Kedua, penulis menggunakan metode observasi ${ }^{13}$ melalui wawancara dengan mahasiswi yang pernah mengalami luka batin untuk mendapatkan data yang benar-benar akurat.

\section{Batas Penelitian}

Mengingat masalah luka batin begitu luas, maka dalam penulisan skripsi ini, penulis membatasi diri dengan memfokuskan pada suatu topik yaitu dampak luka batin terhadap pelayanan Mahasiswi di STTJ Makassar.

\section{Kepustakaan}

Allender, Dan B. Hati Yang Luka. Jakarta: BPK Gunung Mulia, 2001.

Brotosudarmo, Drie S. Etika Kristen Untuk Perguruan Tinggi. Yogyakarta: ANDI 2007.

Hill, Harriet, Richard Bagge, dan Pat Miersma. Menyembuhkan Luka Batin Akibat Trauma. Jakarta: Gloria Graffa, 2006.

Hines, William. Meninggalkan Masa Lalu. Jakarta: IMMANUEL 2009.

Hoft, Irene. Anda Merasa Ditolak. Jakarta: BPK Gunung Mulia, 2011.

Pandie, Mira M., Ivan Th. J. Weismann. "Pengaruh Cyberbullying Di Media Sosial Terhadap Perilaku Reaktif Sebagai Pelaku Maupun Sebagai Korban Cyberbullying Pada Siswa Kristen SMP Nasional Makassar." Jurnal Jaffray 14, no. 1 (2016). http://dx.doi.org/10.25278/jj71.v14i1.188

Simanjuntak, Julianto. Seni Merayakan Hidup Yang Sulit. Jakarta: Gramedia Pustaka Utama, 2008.

Simanjuntak, Julianto. Mengenali Monster Pribadi. Tangerang: PELIKAN Indonesia, 2013.

Wijaya, Hengki (ed.). Metodologi Penelitian Pendidikan Teologi. Makassar: Sekolah Tinggi Theologia Jaffray, 2016.

${ }^{13}$ Observasi adalah pengamatan dan pencatatan yang sistematis terhadap fenomena yang hendak diteliti. Hengki Wijaya (ed.), Metodologi Penelitian Pendidikan Teologi (Makassar: Sekolah Tinggi Theologia Jaffray, 2016), 21. 
